\title{
PALMD wt Allele
}

National Cancer Institute

\section{Source}

National Cancer Institute. PALMD wt Allele. NCI Thesaurus. Code C105938.

Human PALMD wild-type allele is located in the vicinity of 1p22-p21 and is approximately $49 \mathrm{~kb}$ in length. This allele, which encodes palmdelphin protein, may be involved in plasma membrane dynamics. 